\title{
MIGRATIONS OF WADERS (Charadrii) \\ IN THE MIDDLE ODRA VALLEY (W POLAND)
}

\author{
Marcin Bocheński, Paweł Czechowski and Leszek Jerzak
}

\begin{abstract}
Bocheński M., Czechowski P., Jerzak L. 2006. Migrations of waders (Charadrii) in the middle Odra valley (W Poland). Ring 28, 1: 3-18.

Studies were conducted in 1994-2005, in the middle Odra valley (western Poland), between localities: Bytom Odrzański and Kunice $(155 \mathrm{~km})$. During research 1535 controls of different parts of valley were made. There were recorded 26 Charadrii species. Regular occurrence and migrations were observed only for a few of them: Little Ringed Plover (Charadrius dubius), Golden Plover (Pluvialis apricaria), Lapwing (Vanellus vanellus), Ruff (Philomachus pugnax), Common Snipe (Gallinago gallinago), Curlew (Numenius arquata), Redshank (Tringa totanus), Grenshank (T. nebularia), Green Sandpiper (T. ochropus), Wood Sandpiper (T. glareola) and Common Sandpiper (Actitis hypoleucos). There were a few observations of rare in Poland - Sociable Plover (Vanellus gregarius) - or usually uncommon inland species Oystercatcher (Haematopus ostralegus), Great Snipe (Gallinago media), Bar-tailed Godwit (Limosa lapponica) and Whimbrel (Numenius phaeopus). Two features characterizing the waders' passages in the Lubusian part of Odra valley can be told. Firstly, the abundance of migrating birds is usually lower than in other areas, especially when comparing autumn numbers to big inland reservoirs and some ponds complexes. Secondly, the middle part of Odra valley plays more important role during spring than during autumn passage, especially for Lapwings and Golden Plovers.
\end{abstract}

M. Bocheński, L. Jerzak, Division of Nature Protection, Institute of Biotechnology and Environmental Sciences, University of Zielona Góra, Monte Cassino 21B, PL-65-561 Zielona Góra, Poland, E-mail: M.Bochenski@ibos.uz.zgora.pl, L.Jerzak@ibos.uz.zgora.pl; P. Czechowski, Institute for Tourism and Recreation, State Higher Vocational School in Sulechów, Armii Krajowej 51, PL-66-100 Sulechów, Poland, E-mail: paczech@wp.pl

Key words: waders, Charadrii, migration dynamics, middle Odra valley, lubuskie province.

\section{INTRODUCTION}

Migrations of the waders through Poland territory are quite well known and widely described in literature. However, most of this papers deal with two kinds of areas: coast of the Baltic Sea (e.g. Sikora et al. 1994, Meissner and Sikora 1995, Zieliński 1995, Gromadzka and Zieliński 1996, Meissner and Włodarczak 1998) 
or big inland reservoirs and different complexes of ponds (e.g. Cieślak et al. 1991, Stawarczyk et al. 1996, Zieliński and Studziński 1996, Dyrcz et al. 1998, Janiszewski et al. 1998, Witkowski and Ranoszek 1998, Kruszyk and Zbroński 2002a, Szyra 2004). On the other hand, there are not many publications treating waders' passages along Polish inland rivers. Usually there are articles about single or only several species (e.g. Cenian and Sikora 1997, Mitrus et al. 1998) or general migration descriptions included in faunistic papers about avifauna of a given river valley (e.g. Bednorz 1995, Wiehle et al. 2002, Cenian and Sikora 2003). An exception is the paper of Wójcik et al. (1999) focused on spring migration of waders in the lower Vistula valley. In the case of the River Odra some data about Charadrii migrations can be found in the works of Borowiec and Tarnawski (1982) and Stajszczyk (1994). Nevertheless, both deal with upper part of the Odra valley. There is also a work about migration of waders in the lower Odra valley, but it refers to the German side (Kube 1988). As for the middle part of valley, there are only three papers and all they just partly include characteristic of appearance of waders. These are works: (1) by Czechowski et al. (2004) - about rare birds of lubuskie province, (2) by Jędro et al. (2004) - about big flocks of Lapwings and Golden Plovers recorded near village Bieganów and (3) by Bocheński et al. (2006) - where only general description of waders migrations is given. The aim of this paper is to fill this gap describing in detail waders' migration through the middle part of Odra valley and to define importance of this area for migrating waders.

\section{STUDY AREA}

Studies were conducted in the middle Odra valley, including most of its part in lubuskie province, between localities: Bytom Odrzański and Kunice, along the length of $155 \mathrm{~km}$ (Fig. 1).

Depending on the place, width of the valley reaches 1 to $7 \mathrm{~km}$. The valley is mostly covered by forests, growing between river embankments and only occasionally exceeding it. The biggest forest complexes are: near town of Nowa Sól, near villages Tarnawa, Wielobłoto, Przytoczki and downstream to village Cigacice. Most of the tree-stands consist of broad-leaved, mainly oak-hornbeam forests, usually strongly affected by human. In the area of embankments, there are fragments of poplar-willow and elm-ash riverside carrs, also transformed strongly. Besides, there are remains of alder and ash-alder carrs, and in the drier areas - pine monocultures.

Out of the embankments, there are arable fields, fallows, and less commonly meadows and pastures. The largest areas of flooding grass-lands are: upstream to Krosno Odrzańskie ("Czarna Łacha"), near village Czarnowo and on the river polder near villages Krzesin and Bytomiec. Downstream to Kłopot, near villages Rybojedzko and Bieganów, the valley is highly meliorated and there are large areas of intensively farmed arable fields, semi-natural meadows and pastures.

In the river-bed, there are not numerous and small sand-banks, whereas with very low water level, sandy river-banks and fragments of muddy bottom appear. 


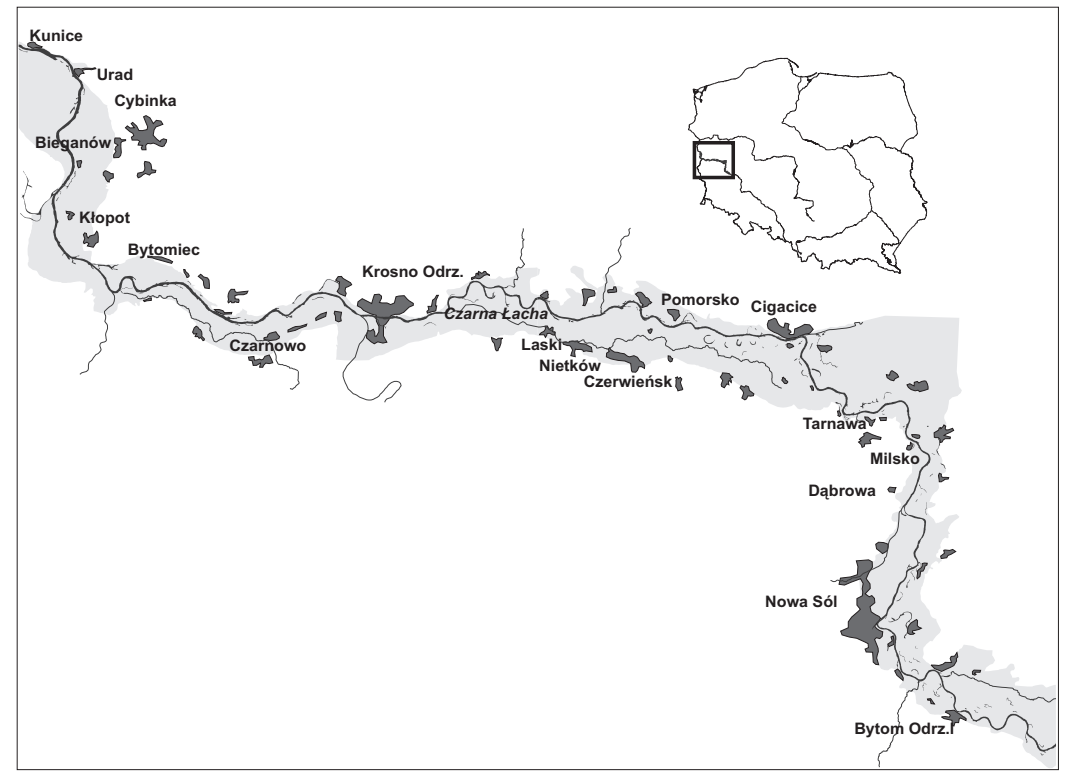

Fig. 1. The study area

Reed- and sedge-beds appear mainly out of the main river-bed, around creeks and cut-offs.

\section{MATERIAL AND METHODS}

The researches were conducted in 1994-2005. During this time, 1535 controls of different parts of the Odra valley were made (Table 1). Although the investigations started in 1994, the main part of the material was collected in 1997-2002. Then, over 1200 controls were made, mainly between Bytom Odrzański and Krosno Odrzańskie. In 2003-2005 studies were concentrated mostly downstream to the Nysa Łużycka mouth, especially on the fragment from Kłopot to Urad villages. Then, 150 further controls were made.

Each control lasted from 2 to 12 hours, and covered length of the valley from 2 to even $30 \mathrm{~km}$. Some of the night controls, especially in the spring time, were made as well.

During each control, all observations of waders were noted, including both birds resting or foraging on the ground and birds passing through.

Regarding the very large study area and, at the same time, the great variance of controls' quality, for the most numerous species the dynamics of abundance is given as a total number of observations and a total number of individuals observed in a given period.

In Results, after the name of each species the total numbers of individuals and observations are given. 
Table 1

Number of controls

\begin{tabular}{|l|r|r|r|r|r|r|r|r|r|r|r|r|r|}
\hline & 1994 & 1995 & 1996 & 1997 & 1998 & 1999 & 2000 & 2001 & 2002 & 2003 & 2004 & 2005 & Total \\
\hline Jan. & & 2 & 7 & 13 & 20 & 23 & 14 & 15 & 10 & 6 & 3 & 8 & $\mathbf{1 2 1}$ \\
\hline Feb. & & & 4 & 13 & 22 & 19 & 15 & 16 & 8 & 3 & 4 & 6 & $\mathbf{1 1 0}$ \\
\hline Mar. & & 8 & 11 & 18 & 26 & 24 & 19 & 17 & 14 & 6 & 6 & 9 & $\mathbf{1 5 8}$ \\
\hline Apr. & 1 & 3 & 7 & 20 & 24 & 26 & 26 & 17 & 15 & 6 & 6 & 14 & $\mathbf{1 6 5}$ \\
\hline May & 1 & 1 & 7 & 24 & 26 & 28 & 21 & 22 & 12 & 8 & 11 & 8 & $\mathbf{1 6 9}$ \\
\hline Jun. & & 3 & 2 & 17 & 17 & 20 & 15 & 17 & 9 & 9 & 7 & 12 & $\mathbf{1 2 8}$ \\
\hline Jul. & & & & 5 & 16 & 10 & 18 & 22 & 10 & 4 & 4 & 5 & $\mathbf{9 4}$ \\
\hline Aug. & & 1 & & 21 & 14 & 18 & 21 & 18 & 4 & 4 & 6 & 10 & $\mathbf{1 1 7}$ \\
\hline Sep. & 1 & 2 & 1 & 21 & 19 & 15 & 17 & 17 & 7 & & 5 & 10 & $\mathbf{1 1 5}$ \\
\hline Oct. & 3 & 4 & 2 & 25 & 19 & 14 & 13 & 12 & 4 & 3 & 8 & 11 & $\mathbf{1 1 8}$ \\
\hline Nov. & & & 5 & 24 & 19 & 14 & 10 & 5 & 7 & 2 & 6 & 5 & $\mathbf{9 7}$ \\
\hline Dec. & 2 & 8 & 16 & 27 & 26 & 15 & 14 & 9 & 9 & 3 & 9 & 5 & $\mathbf{1 4 3}$ \\
\hline Total & $\mathbf{8}$ & $\mathbf{3 2}$ & $\mathbf{6 2}$ & $\mathbf{2 2 8}$ & $\mathbf{2 4 8}$ & $\mathbf{2 2 6}$ & $\mathbf{2 0 3}$ & $\mathbf{1 8 7}$ & $\mathbf{1 0 9}$ & $\mathbf{5 4}$ & $\mathbf{7 5}$ & $\mathbf{1 0 3}$ & $\mathbf{1 5 3 5}$ \\
\hline
\end{tabular}

\section{RESULTS}

Oystercatcher (Haematopus ostralegus) $-N_{o b s}=4, N_{\text {ind }}=5$. Seen only during spring migration. Single individuals were observed on: 9 May 1998 near Milsko, 12 Apr. 1999 near Cigacice and 12 Apr. 1998 near Czarnowo. Additionally, 2 indiv. were observed on 14 May 1996 also near Czarnowo.

Little Ringed Plover (Charadrius dubius) $-N_{\text {obs }}=143, N_{\text {ind }}=358$. The earliest bird was seen on 23 Mar. 2005 near Bieganów. During spring passage usually 1-4 birds were observed. The most abundantly and frequently it appeared in the midApril - up to 8 indiv. on 21 Apr. 2000 near Nowa Sól (Fig. 2). During summer, mainly breeding birds were recorded (Czechowski et al. 2002). In July, frequency of observations and number of individuals was increasing, while families with young birds were appearing. Inappreciable peak of autumn migration occurred at the end of August. Last individuals were seen until the mid-September.

Ringed Plover (Charadrius hiaticula) $-N_{\text {obs }}=13, N_{\text {ind }}=17$. Twice seen during spring time (on 18 Mar. 1999 near Nowa Sól and on 4 May 1994 near Laski), once in July and five times in August and September. Last observation was on 18 Sep. 1998 near Krosno Odrz. All records dealt with one or two individuals.

Golden Plover (Pluvialis apricaria) $-N_{\text {obs }}=80, N_{\text {ind }}=9641$. Observed regularly during spring passages. First birds were recorded as early as at the beginning of February, with the earliest observation of, unusual for this time, big flock - 500 indiv. on 8 Feb. 2004 near Bieganów. The most numerous in the second half of March (Fig. 2), when flocks up to 1500 birds in the arable fields near Bieganów were noted (Jędro et al. 2004). In the spring time, last birds were observed in the second half of April. 

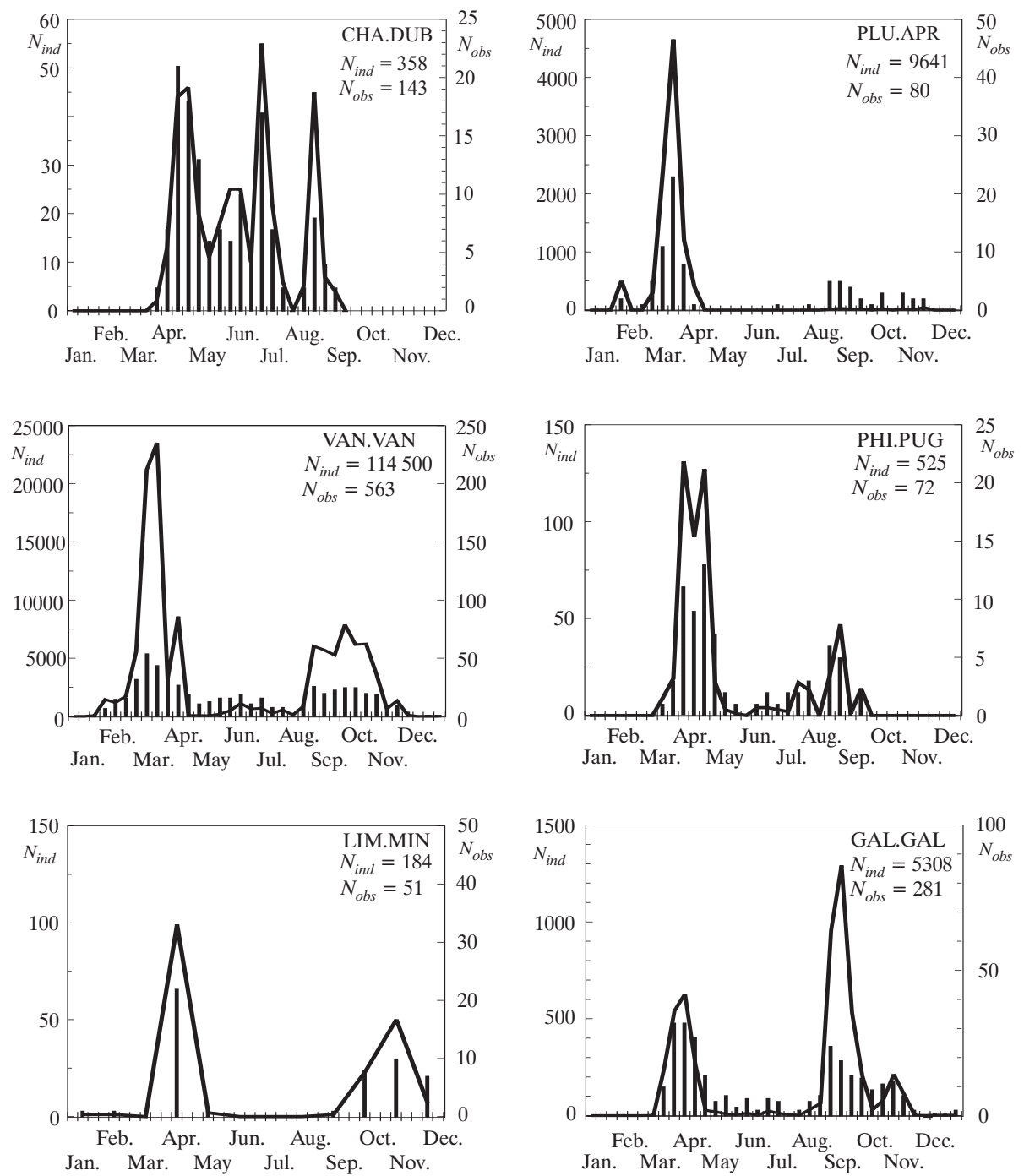

Fig. 2. Number dynamics of some bird species: CHA.DUB - Charadrius dubius, PLU.APR - Pluvialis apricaria, VAN.VAN - Vanellus vanellus, PHI.PUG - Philomachus pugnax, LIM.MIN - Limnocryptes minimus, GAL.GAL - Gallinago gallinago. Line - total number of individuals (left axis) recorded in decades or months (in the case of the Jack Snipe), bars - total number of observations (right axis) in a given period.

In autumn there were only 29 records, mostly in September. The most numerous autumn flock -22 indiv. was noticed on 21 Nov. 2001 near Krosno Odrz. The latest observation (18 indiv.) took place on 27 Nov. 2004 near Bieganów.

Grey Plover (Pluvialis squatarola) $-N_{o b s}=5, N_{\text {ind }}=7$. Only one spring observation of a single bird was made on 16 May 1999 near Nowa Sól. Further four autumn observations come from: 26 Sep. 2001 - 3 indiv. near Bieganów, 1 Oct. 2001 - 1 indiv. near Cigacice, 23 Oct. $1999-1$ indiv. near Pomorsko and 6 Nov. $1999-1$ indiv. near Nowa Sól. 
Sociable Plover (Vanellus gregarius) $-N_{\text {obs }}=1, N_{\text {ind }}=1$. One adult bird was observed on 12 Apr. 1997 near Laski (Czechowski and Sidelnik 2001).

Lapwing (Vanellus vanellus) $-N_{\text {obs }}=563, N_{\text {ind }}=114496$. Usually first observations were recorded as early as at the beginning of February, with the earliest one on 31 Jan. 2002 - 70 indiv. near Laski. The average date of arrival fell on 15 Feb. $(N=8)$. The peak of spring migration occurred in the second half of March (Fig. 2), when Lapwings were seen in concentrations over thousand and even up to 5000 indiv. Nevertheless, the biggest flock ( 8300 birds) was observed on 14 Apr. 2003 on the fields and meadows near Bieganów (Jędro et al. 2004). Spring migration was extended to the end of April.

First flocks, consisting of up to 160 indiv., starting their autumn migration were observed as early as at the beginning of June. Passage was very intensive in time but less abundant than during spring. Its peak appeared on the turn of September. The biggest autumn flock (4000 indiv.) was recorded on 21 Sep. 2005 near Bieganów. Usually last Lapwings were noted in November. Exceptionally late, single individuals were observed on 19 Dec. 2000 near Czerwieńsk and on 22 Dec. 2000 near Laski.

Little Stint (Calidris minuta) $-N_{\text {obs }}=7, N_{\text {ind }}=31$. Observed twice in August 1999: on 22 Aug. -3 and on 24 Aug. -1 indiv. Four times recorded in September 1998 near Krosno Odrz.: on 1, 5 and 18 Sep. - 5 indiv., and on 4 Sep. - 11 indiv. on Czarna Łacha near Krosno Odrz.

Temminck's Stint (Calidris temminckii) $-N_{\text {obs }}=7, N_{\text {ind }}=11$. Single birds were observed six times in May: on 6, 27, 28 May 1998, on 10 May 1999 and on 5 May 2000 near Nowa Sól, and on 28 May 1999 on Czarna Łacha near Krosno Odrz. Once, 5 birds were noted on 5 Aug. 2004 near Brody (Czechowski et al. 2004).

Curlew Sandpiper (Calidris ferruginea) $-N_{o b s}=7, N_{\text {ind }}=13$. Single birds were recorded on 17 Sep. 1997 near Laski and on 4 and 5 Sep. 1998 near Krosno Odrz. Four observations in Sep. 1999 near Nowa Sól: on 22 Sep. - 7 indiv. and on 24, 27, 28 Sep. -1 indiv.

Dunlin (Calidris alpina) $-N_{\text {obs }}=26, N_{\text {ind }}=73$. Seven records during spring time. The earliest observation come from 12 Mar. 1999 - 1 indiv. near Laski. Three times it was seen in March 2005 near Bieganów (on 18 and 23 Mar. - 2 indiv. and on 28 Mar. - 10 indiv.) and there were further three observations of 3 indiv. - on 2, 4 and 10 Apr. 2000 on Czarna Łacha, near Krosno Odrz.

During autumn passage it was seen: once in July (31 Jul. 2001 - 1 indiv. near Nowa Sól), four times in August, eight times in September and three times in October (with the latest on 9 Oct. 2004 - 2 indiv. near Urad and 1 indiv. near Kunice). Usually there were seen 1-3 indiv., but on 12 Sep. 1997 - 9 indiv. and on 14 Sep. 1997 - 14 indiv. were observed near Nowa Sól.

Ruff (Philomachus pugnax) $-N_{o b s}=72, N_{\text {ind }}=525$. In spring, first Ruffs were noticed in the second half of March, with the earliest observation on 18 Mar. 2005 9 indiv. near Bieganów. The most numerously Ruffs were observed in April (Fig. 2). 
Usually there were seen flocks up to 25 indiv. and once (exceptionally) 59 birds on 10 Apr. 2000 on Czarna Łacha.

Autumn migration started quite early, in the second half of June. The earliest observation comes from 19 Jun. $2001-4$ males near Bieganów. In total recorded: 3 times in June ( 8 indiv.), 5 in July (16 indiv.), 9 in August (34 indiv.) and 8 in September (62 indiv.). Usually seen in flocks of several birds and the largest - 19 indiv. on 5 Sep. 1997 near Nowa Sól. The latest observation (of 5 Ruffs) comes from 29 Sep. 2001, near Bieganów.

Jack Snipe (Lymnocryptes minimus) $-N_{\text {obs }}=51, N_{\text {ind }}=184$. In spring observed 22 times in April (with the earliest on 1 Apr. 1999 - 2 indiv. near Laski and on 1 Apr. 2000 - 1 indiv. near Nowa Sól) and once in May (2 May 2001 - 2 indiv. near Nowa Sól). In autumn, 19 records including: 1 in September (29 Sep. $2001-1$ indiv. near Cigacice), 8 in October and 10 in November (with the latest on 11 Nov. $1999-1$ indiv. near Nowa Sól). Usually there were seen several individuals. The most numerous records were: in spring - 15 indiv. on 14 Apr. 2001 near Nowa Sól, in autumn 30 indiv. on 2 Nov. 2001 near Pomorsko. During winter (December-February), single birds were noted 9 times (Fig. 2). It is important to mention, that recording of this species requires special methods of searching. These were not applied during all controls. Inspections aiming to find Jack Snipes were conducted mainly in 2000 and 2001.

Great Snipe (Gallinago media) $-N_{\text {obs }}=1, N_{\text {ind }}=1$. One bird was noted on 30 Aug. 2001 near Nietków (Czechowski et al. 2004).

Common Snipe (Gallinago gallinago) $-N_{\text {obs }}=281, N_{\text {ind }}=5308$. The spring migration started usually in the first half of March. The earliest observation (1 indiv.) was made on 5 Mar. 1997 near Laski. The peak of the passage appeared on the turn of March (Fig. 2). Usually there were recorded concentrations up to dozens birds. Exceptionally, in 2000 - while there was high water level on the Odra; flocks up to 150 snipes were noted. At the end of April migration faded and then mostly breeding birds were observed (Czechowski et al. 2002).

Extended in time and usually less numerous autumn passage started mostly on the turn of June. Two peaks of it occurred: the first one - on the turn of August and the second and less numerous one - at the end of October. Mostly, flocks of a few or dozen birds were noted. Unusually high numbers of Snipes were observed after summer floods: in 1997 - up to 300 indiv. near Nowa Sól and in 2001 - over 200 indiv. near Nowa Sól and in the same year, up to 120 indiv. near Pomorsko and Nietków. The latest, probably trying to winter, single birds were observed twice at the end of December: on 28 Dec. 2000 near Milsko and on 28. Dec. 2001 near Nowa Sól.

Woodcock (Scolopax rusticola) $-N_{\text {obs }}=5, N_{\text {ind }}=6$. Observed only in spring. Single birds were noted: on 21 Mar. 1996 near Laski, on 31 Mar. 1996 near Tarnawa, on 25 Mar. 1997 near Laski and on 7 Apr. 2000 on Czarna Łacha. Once, 2 birds were observed on 8 Apr. 1996 near Tarnawa. 
Black-tailed Godwit (Limosa limosa) $-N_{o b s}=11, N_{\text {ind }}=21$. Observed entirely in spring: once in March (25 Mar. 2000 - 2 indiv. on Czarna Lacha), eight times in April and twice in May. Usually there were seen 1 or 2 birds, once 4 indiv. (on 10 Apr. 2004 on Czarna Łacha) and once 5 indiv. (on 10 Apr. 2000 on Czarna Łacha).

Bar-tailed Godwit (Limosa lapponica) $-N_{o b s}=2, N_{\text {ind }}=2$. Single birds were observed: on 20 Jun. 1997 - an adult individual near Laski (Czechowski et al. 2004) and on 1 Sep. 2005 - a young bird near Bieganów.

Whimbrel (Numenius phaeopus) $-N_{\text {obs }}=4, N_{\text {ind }}=4$. Single birds were noted four times: on 2 Apr. 1999 near Laski, on 4 May 1999 near Czerwieńsk, on 20 Apr. 2000 near Nowa Sól and on 28 Apr. 2000 near Czarnowo.

Curlew (Numenius arquata) $-N_{\text {obs }}=79, N_{\text {ind }}=128$. Curlews were observed from March (first record on 5 Mar. 1997 - 1 indiv. near Laski) to September (last observation on 21 Sep. 2002 - 1 indiv. on Czarna Łacha), but irregularly (Fig. 3). Some of the records from period: end of March - May dealt with the breeding birds. Usually there were seen single birds and much less commonly - in the number of 2-7 individuals. The biggest flocks ( 8 birds) were noted on 22 Jun. 1995 near Laski and on 20 Aug. 1997 near Pomorsko.

Spotted Redshank (Tringa erythropus) $-N_{o b s}=31, N_{i n d}=241$. Ten observations in the spring time: 9 in April (with the earliest on 10 Apr. 2000 - 1 indiv. on Czarna Łacha) and 1 in May (1 May 2005 - 1 indiv. near Bieganów). Usually there were single birds and the biggest flock was 12 indiv. on 18 Apr. 1998 near Nowa Sól.

During autumn migration, there were 21 records: 4 in June (first on 9 Jun. 2002 near Czerwieńsk), 7 in August, 9 in September and 1 in November (11 Nov. 1997 - 1 indiv. near Nowa Sól). Mostly, there were single birds or flocks up to 10 indiv. The highest numbers of flocks were recorded in September 1997 near Nowa Sól (up to 83 indiv. on 14 Sep.).

Redshank (Tringa totanus) $-N_{\text {obs }}=60, N_{\text {ind }}=145$. Observed mainly in spring: 9 times in March, 25 in April and 9 in May (Fig. 3). The earliest record comes from 17 Mar. 2002 - 1 indiv. on Czarna Łacha. Mostly, there were seen flocks up to 8 birds, once (exceptionally) - 20 indiv. on 3 May 1996 on Czarna Łacha. During autumn migrations seen: 8 times in June, 2 in July, 5 in August, 1 in September and November (29 Nov. 1997 - 1 indiv. near Nowa Sól). In this period usually there were seen flocks of 1-3 birds, and once - 7 indiv. on 10 Jun. 1996 on Czarna Łacha. Some of the May and June observations dealt with the breeding birds (Czechowski et al. 2002, authors unpubl.).

Greenshank (Tringa nebularia) $-N_{o b s}=120, N_{\text {ind }}=395$. Spring migration started at the beginning of April (first observations: on 4 Apr. 1999 - 2 indiv. near Nowa Sól and on 4 Apr. 2000 - 3 indiv. on Czarna Łacha) and its peak appeared in the second half of this month (Fig. 3). Passage faded out in the mid-May, (last spring records of single birds on 14 May 1996 near Krosno Odrz. and on 14 May 1998 near Nowa Sól). Usually seen up to several birds and the biggest flock (36 indiv.) was observed on 17 Apr. 1999 near Nowa Sól. 

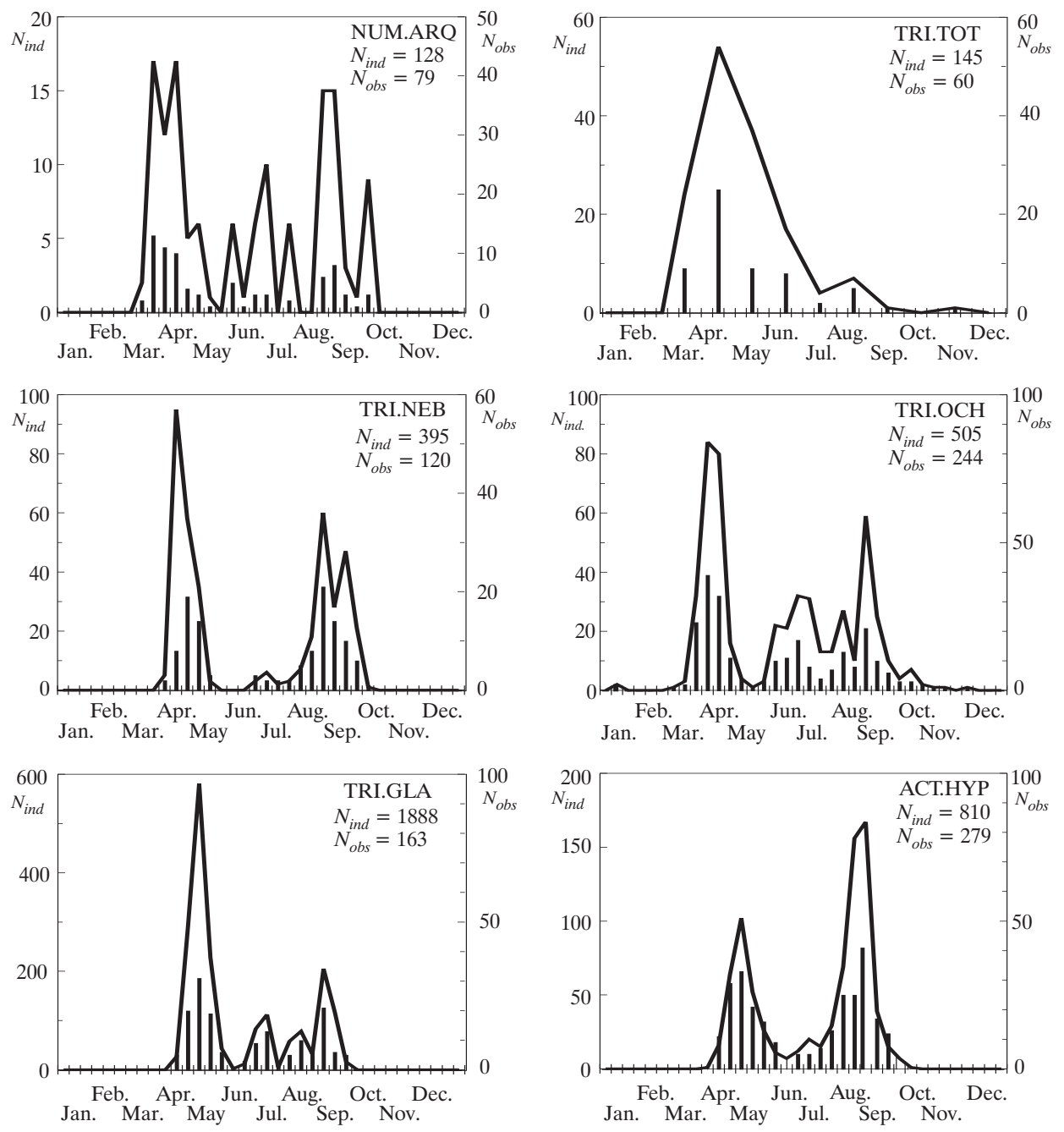

Fig. 3. Number dynamics of some bird species: NUM.ARQ - Numenius arquata, TRI.TOT - Tringa totanus, TRI.NEB - Tringa nebularia, TRI.OCH - Tringa ochropus, TRI.GLA - Tringa glareola, ACT.HYP - Actitis hypoleucos. Explanations as in Fig. 2.

Longer, but less numerous, autumn migration started at the end of June, (first record - one bird on 21 Jun. 2002 near Nietków), and its peak occurred at the end of August. Usually several individuals were observed and the biggest flock comprised 16 birds (on 21 Aug. 2001 near Nowa Sól). Last record comes from 6 Oct. 1997 - 1 indiv. near Nowa Sól.

Green Sandpiper (Tringa ochropus) $-N_{o b s}=244, N_{\text {ind }}=505$. Spring migration started in the second half of March (Fig. 3), although first record comes from 5 Mar. 1997 - 1 indiv. near Laski. The peak appeared in the first half on April. 
Usually, 1-4 indiv. were seen and the most numerous concentration was on 10 Apr. 2000 - 10 indiv. on Czarna Lacha. Passage faded out in May, and lately mostly breeding birds were observed (Czechowski et al. 2002).

Long autumn migration started as early as at the beginning of June and ended usually in the second half of October. Two distinct peaks could be distinguished: the first one - on the turn of June and the second one - at the end of August and beginning of September. The latest observation comes from 26 Nov. $1995-1$ indiv. near Tarnawa. As a rule several birds were recorded and the most numerous concentration (12 indiv.) was noted on 21 Aug. 1997 near Nowa Sól. Besides, in the midJanuary 2000, two single birds were noted: on 15 Jan. near Tarnawa and on 16 Jan. near Nowa Sól.

Wood Sandpiper (Tringa glareola) $-N_{o b s}=163, N_{\text {ind }}=1888$. Spring passage started in the mid-April (with the earliest record on 14 Apr. $2002-2$ indiv. near Nowa Sól) and its peak occurred in the first decade of May (Fig. 3). Last birds were still seen in June. Usually, flocks of dozens birds were seen, with the maximum number of 95 indiv. on 1 May 2000 near Nowa Sól.

Autumn passage was extended in time and less abundant than in the spring time. Its beginning was hardly distinguishable from the end of spring migration. Commonly several birds were recorded, but in 1997 and 2001 there were seen flocks of dozens birds. The largest one (52 indiv.) was observed on 21 Aug. 2001 near Nowa Sól. The latest observations come from 18-19 Sep. 1998 - 1 indiv. near Krosno Odrz.

Common Sandpiper (Actitis hypoleucos) $-N_{\text {obs }}=279, N_{\text {ind }}=810$. As a rule first birds appeared in the mid-April, although the earliest record comes from 4 Apr. $1998-1$ indiv. near Tarnawa. The peak of spring migration occurred in the first decade of May and then faded out (Fig. 3). Up to 9 indiv. were seen. Most of the records from June and July dealt with breeding birds (Czechowski et al. 2002).

Autumn migration started in the second half of July and its peak appeared in the second half of August. Usually during controls several birds were noted and the biggest concentrations numbered 23 indiv. (on 13 and 15 Aug. 1997 near Nowa Sól). The passage usually finished at the end of September, with the latest record from 11 Oct. 1998 - 1 indiv. near Nowa Sól.

\section{DISCUSSION}

In the middle part of the Odra valley 26 wader species were recorded out of 57 observed in Poland (Avifaunistic Commission 2006). It is less than in the region of Gulf of Gdańsk at the Baltic Sea, where 41 species were noted (Sikora et al. 1994, Meissner and Sikora 1995) and on the most of inland retention reservoirs (e.g. Jeziorsko, Kostrzyński, Mietkowski, Nyski, Turawski, Wonieść), some marshlands (e.g. Błota Rakutowskie) and the biggest fishponds complexes (e.g. in Barycz or in upper Vistula valleys, near Przemków), where 31-39 waders species were seen (Cieślak et al. 1991, Kuźniak and Lorek 1993, Witkowski et al. 1995, Stawarczyk et al. 1996, Zieliński and Studziński 1996, Dyrcz et al. 1998, Janiszewski et al. 1998, 
Bartoszewicz et al. 2000, Wiehle et al. 2002) and, finally, less than in the lower Odra valley with 30 species (Kube 1988). The proportionally low number of Charadrii species in described area follows the lack of the records of many species rare in Poland - e.g. Pectoral Sandpiper (Calidris melanotos), Buff-breasted Sandpiper (Tryngites subruficollis), Terek Sandpiper (Xenus cinereus); or not common inland the country - e.g. Red-necked Phalarope (Phalaropus lobatus), Sanderling (Calidris alba), Knot (Calidris canutus) and which were observed on areas listed above. On the other hand, in the middle Odra valley, there were some observations of this kind of species - e.g. Oystercatcher, Social Plover, Great Snipe, Bar-Tailed Godwit, Whimbrel. Similar to the middle Odra valley the lower number of species were observed in some other regions of Poland (Gramsz 1991; Stajszczyk 1994; Staszewski and Kaliciuk 1995; Słychan 1996; Wysocki 1996; Kasprzykowski et al. 1999; Kruszyk and Zbroński 2002a, 2002b; Martyka and Skórka 2002; Szyra 2004; Szyra and Szyra 2004).

Although in the described area 26 species of Charadrii were noted, the regular occurrence and migration only for a few of them were observed.

Contrary to other regions of Poland (e.g. Meissner and Sikora 1995, Stawarczyk et al. 1996, Zieliński and Studziński 1996, Janiszewski et al. 1998, Witkowski and Ranoszek 1998, Kruszyk and Zbroński 2002a), spring passage of the Little Ringed Plover in the middle Odra valley was slightly more obvious than in autumn. However, the migration dynamics during spring was similar to other sites, with the highest abundance in April. Also, like on the big inland reservoirs and in the lower Odra valley - the first peak of abundance during autumn migration occurred in the July, when local families and first migrants were observed together (Kube 1988, Stawarczyk et al. 1996, Dyrcz et al. 1998, Janiszewski et al. 1998, Kruszyk and Zbroński 2002a). The second peak was observed in the second half of August, as in the central or southern part of Poland (Słychan 1996, Dyrcz et al. 1998, Janiszewski et al. 1998, Witkowski and Ranoszek 1998), and it was later than in the north of Poland (Meissner and Sikora 1995, Zieliński and Studziński 1996).

Opposite to the most of other regions of Poland, spring migration of Golden Plovers and Lapwings in the middle part of Odra valley was more intensive than in autumn. The first mentioned species was regularly observed here during spring migration, reaching abundance even up to 1500 indiv. Regular passage of the Golden Plover was observed also only in the lower parts of Odra and Vistula valleys. And in this second case, like in the middle Odra, big flocks up to 1000 indiv., were observed. In comparison to these areas, the migration in the middle Odra valley started, reached the peak of abundance and finished earlier (Kube 1998, Wójcik et al. 1999). In other regions, there were usually not more than a few observations or the passage was not plentiful. On the other hand, in the middle Odra valley in autumn there were only 29 observations of Golden Plovers and abundance of flocks did not exceed 22 birds, while in other regions it was a regularly migrating species, with concentrations reaching over 250 indiv. (Cieślak et al. 1991, Meissner and Sikora 1995, 
Stawarczyk et al. 1996, Dyrcz et al. 1998, Janiszewski et al. 1998, Witkowski and Ranoszek 1998, Szyra 2004).

The phenology of occurrence and migration dynamics of the Lapwing in Odra valley were quite similar to other areas in Poland, with the peak of spring migration in March and long, multi-peaked autumn passage. However, the numbers were different. In the studied area, during springtime Lapwings were very abundant, and concentrations reached even five thousands of individuals. On the other hand, autumn flocks usually comprised several hundred individuals, rarely reaching more than one thousand and only exceptionally - four thousand of birds. Similar patterns of Lapwing migration were observed also in the lower Odra and Vistula valleys and in the inland Błota Rakutowskie marshlands (Zieliński and Studziński 1996, Kube 1988, Wójcik et al. 1999). In other regions, spring passage was less abundant and migrating flocks usually numbered several hundred birds, while autumn concentrations often reached even several thousand individuals (Cieślak et al. 1991, Stychan 1996, Stawarczyk et al. 1996, Dyrcz et al. 1998, Janiszewski et al. 1998, Witkowski and Ranoszek 1998, Szyra 2004). The spring concentration of 8300 Lapwings near Bieganów was the biggest spring flock of this species recorded in Poland (Jędro et al. 2004).

Similarly to the region of the Gulf of Gdańsk, most of the inland reservoirs and complexes of ponds, the spring migration of Ruffs in the middle Odra valley was characterized by the peak of abundance in April. It was more intensive than in autumn, however, usually with much lower numbers of birds than in other areas (Cieślak et al. 1991, Stajszczyk 1994, Meissner and Sikora 1995, Stychan 1996, Zieliński and Studziński 1996, Witkowski and Ranoszek 1998, Wójcik et al. 1999, Kruszyk and Zbroński 2002a, Szyra 2004).

Due to the lack of regular controls aiming to detect the Jack Snipe, migration of this species in the middle part of Odra valley is hard to describe. Nonetheless, the high abundance in April overlaps with the peak of its spring migration through Poland and winter observations suggest regular wintering of Jack Snipes in the Lubusian part of the Odra valley (Tomiałojć and Stawarczyk 2003).

Spring migration of the Common Snipe in the middle Odra valley was similar to other inland areas in Poland, where, as a rule, it was not intensive. Its peak occurred on the turn of March, at the same time as it was recorded in the lower Odra and Vistula valleys (Kube 1988, Wójcik et al. 1999) and earlier than at the coasts of the Gulf of Gdańsk (Meissner and Sikora 1995, Meissner and Włodarczak 1998). It was explained by earlier melting of ice and faster development of invertebrate fauna in the large rivers valleys, as well as by the occurrence of suitable habitats on studied areas (Meissner 2001a). Nevertheless, comparing to big reservoirs and complexes of ponds, autumn passage was much less abundant, but with still similar number dynamics, i.e. long and usually multi-peaked (Cieślak et al. 1991, Stawarczyk et al. 1996, Zieliński and Studziński 1996, Dyrcz et al. 1998, Janiszewski et al. 1998, Witkowski and Ranoszek 1998, Kruszyk and Zbroński 2002a). 
More spring than autumn observations of Curlews in the middle Odra valley stayed in opposition to inland reservoirs, ponds complexes and Baltic Sea coast, where autumn migration was much more intensive. At the same time, phenology of occurrence during spring was somewhat different. In the described area Curlews arrived earlier (at the beginning of March) and the peak of their passage occurred earlier (at the end of March) than in other regions of Poland. Nevertheless, the migration dynamics in autumn was more similar, with the highest abundance at the end of August (Kube 1988, Cieślak et al. 1991, Meissner and Sikora 1995, Stawarczyk et al. 1996, Zieliński and Studziński 1996, Dyrcz et al. 1998, Janiszewski et al. 1998, Witkowski and Ranoszek 1998).

Like in the upper and lower parts of the Odra valley, inland ponds complexes and marshes, the spring migration of Redshank in the middle Odra was more obvious and abundant than in autumn (Kube 1988, Cieślak et al. 1991, Stajszczyk 1994, Słychan 1996, Zieliński and Studziński 1996, Witkowski and Ranoszek 1998, Kruszyk and Zbroński 2002a).

The pattern of Greenshank migrations in the middle Odra valley was similar to other regions of Poland, with its peak at the end of April in spring, and end of August in autumn, but it was usually much less numerous, especially during autumn passage (Kube 1988, Cieślak et al. 1991, Stawarczyk et al. 1996, Witkowski and Ranoszek 1996, Zieliński and Studziński 1996, Janiszewski et al. 1998, Meissner and Włodarczak 1998, Wójcik et al. 1999, Kruszyk and Zbroński 2002a).

Regular and similar in pattern to the middle Odra valley spring passage of the Green Sandpiper was observed only in the lower Odra valley (Kube 1988), while in other regions it was irregular and not numerous (Cieślak et al. 1991, Stajszczyk 1994, Meissner and Sikora 1995, Stawarczyk et al. 1996, Zieliński and Studziński 1996, Dyrcz et al. 1998, Meissner and Włodarczak 1998, Kruszyk and Zbroński 2002a). The first peak of its autumn migration, in the mid-June, might have been caused by appearing of adult birds after breeding in the Odra valley and adjacent areas and first young individuals. The second peak, observed in the second half of August, was formed by regularly migrating birds.

In the middle Odra valley, the pattern of spring migration of the Wood Sandpiper, with the peak of abundance in the first half of May, was almost the same as in other areas, but as a rule less numerous. However, autumn passage was somewhat different: with three and not two peaks of abundance: the first - on the turn of June, the second - on the turn of July and the last one - at the end of August. Similarly to spring, migration was much less numerous than in other regions (Kube 1988, Cieślak et al. 1991, Meissner and Sikora 1995, Słychan 1996, Stawarczyk et al. 1996, Zieliński and Studziński 1996, Dyrcz et al. 1998, Janiszewski et al. 1998, Meissner and Włodarczak 1998, Witkowski and Ranoszek 1998, Wójcik et al. 1999, Kruszyk and Zbroński 2002a, Szyra 2004).

Migrations of the Common Sandpiper in the middle Odra valley was quite similar to other regions in Poland, with the peak of abundance at the beginning of May 
and at the second half of August, but less numerous. Especially when comparing to large inland reservoirs, where during autumn up to several hundreds individuals were observed (Kube 1988, Stajszczyk 1994, Meissner and Sikora 1995, Stawarczyk et al. 1996, Zieliński and Studziński 1996, Janiszewski et al. 1998, Meissner and Włodarczak 1998, Witkowski and Ranoszek 1998, Kruszyk and Zbroński 2002).

Upon preceding description, two features characterizing the waders' passages in the Lubusian part of the Odra valley can be told. Firstly, the abundance of migrating birds is usually lower than in other areas, especially when comparing autumn numbers to big inland reservoirs and some ponds complexes. Secondly, the middle part of Odra valley plays more important role during spring than autumn passages. There can be several, connected with each other, reasons. As a rule, this part of river valley does not provide proper feeding and resting habitats for waders. Sandbanks in the river-bed are usually small and appear only when the water level in the river is very low. The same situation is with the muddy fragments of bottom, which are restricted only to small parts of river-banks. Additionally, this state is rather uncommon and occurs only in early summer, before migration periods of the majority of species. When the main, very abundant waves of autumn passage appear, inland migrating waders, mostly young birds, meet very good conditions for feeding and resting at the big retention reservoirs and complexes of fish ponds. At this time, such reservoirs are usually almost empty and exhibit large surfaces of muddy bottom. This way, they are preferred by waders to stop there and river valleys such as the middle part of Odra valley are avoided. The reverse situation is during spring time. Most of the fish ponds are filled with water, as well as the retention reservoirs (due to high water level in rivers after snow melting). During high water level in spring, many areas along Odra river-beds are flooded. When this water disappears, sometimes large parts of exposed marshes occur. This provides much better conditions for waders than in the reservoirs or ponds. However, large concentrations of passing waders usually do not occur, because the spring passage of waders is much faster with higher stopover rates than in autumn (Meissner 2001b). In addition, feeding habitats suitable for waders are spread over a very large area along the river and birds do not have to focus on small proper parts, so usually they do not form big concentrations.

Although migrating waders can be seen in almost every part of the middle Odra valley, some fragments can be distinguished, which have notable importance for them. These are: fragment of valley between localities Bytom Odrz. - Dąbrowa, where almost all described waders species were recorded (including all Calidris stints); flooding area upstream to Krosno Odrz. alias "Czarna Łacha", where during high water level relatively large concentrations of e.g. Common Snipes were observed; and part of the valley near Bieganów, where the biggest flocks of Golden Plovers and Lapwings were noted. 


\section{ACKNOWLEDGEMENTS}

We would like to thank our colleagues for taking part in these studies or making their own observations accessible. They were: Jacek Cichocki, Jan Cichocki, Grzegorz Jędro, Zbigniew Kajzer, Maciej Kosmala, Tomasz Krzyków, Piotr Romanowski, Sławek Rubacha, Grzegorz Sawko, Marcin Sidelnik, Andrzej Wąsicki. We are also grateful to Włodzimierz Meissner for his valuable comments on the first drafts of this paper.

\section{REFERENCES}

Avifaunistic Commission. 2006. List of the national avifauna. http://www.biol.uni.wroc.pl/komfaun Bartoszewicz M., Wypychowski K., Engel J. 2000. Numbers of some bird species in the Stońsk Nature Reserve in 1994-1997. Biol. Bull. Poznań 37, 2: 235-255.

Bednorz J. 1995. Birds of the Noteć River valley. Pr. Zakł. Biol. i Ekol. Ptaków UAM. vol. 4. Poznań.

Bocheński M., Kajzer Z., Czechowski P., Jędro G., Cichocki J., Rubacha S., Sidelnik M., Wąsicki A. 2006. Migrating and wintering avifauna of the Odra river valley middle section. Ptaki Śląska 16: 123-161.

Borowiec L., Tarnawski D. 1982. The passages and wintering of birds on the River Oder near Brzeg. Acta zool. cracov. 26: 3-30.

Cenian Z., Sikora A. 1997. Autumn migration of the Jack Snipe Lymnocryptes minimus in the north-western Warmia and Gdańsk coastland in 1996. Not. Orn. 38, 3: 215-222.

Cenian Z., Sikora A. 2003. Avifauna of the Pastęka River valley. Not. Orn. 44: 161-177.

Cieślak M., Czapulak A., Krogulec J. 1991. Birds of nature reserve "Przemków Ponds" and its surroundings. Ptaki Śląska 8: 54-100.

Czechowski P., Bocheński M., Jędro G., Kajzer Z., Rubacha S., Sidelnik M., Wąsicki A. 2004. Rare birds species observed in the province of Ziemia Lubuska in 1990-2004. Not. Orn. 45: 241-253.

Czechowski P., Rubacha S., Wąsicki A. Bocheński M., Jędro G., Kajzer Z., Sidelnik M. 2002. Breeding avifauna of the middle Oder River valley. Not. Orn. 43: 163-176.

Czechowski P., Sidelnik M. 2001. The observation of the Sociable Plover Vanellus gregarius in the Lubusian Region. Przegl. Przyr. 12: 157-158.

Dyrcz A., Kołodziejczyk P., Martini K., Martini M. 1998. Birds of the Mietków Reservoir. Ptaki Śląska 12: $17-80$.

Gramsz B. 1991. Breeding birds of Podgórzyn fish-ponds in 1981-1983. Ptaki Śląska 8: 109-117.

Gromadzka J., Zieliński M. 1996. Ringing of waders (Charadrii) at the Vistula River mouth in 1995-1996. Not. Orn. 37: 344-351.

Janiszewski T., Włodarczyk R., Bargiel R., Grzybek J., Kaliński A., Lesner B., Mielczarek S. 1998. Birds of the Jeziorsko reservoir in 1986-1996. Not. Orn. 39, 3: 121-150.

Jędro G., Bocheński M., Czechowski P., Kosmala M., Rubacha S., Stepek D. 2004. Numerous flocks of Golden Plover Pluvialis apricaria and Lapwing Vanellus vanellus in Lubuska Land. Przegl. Przyr. 15: 140-141.

Kasprzykowski Z., Goławski A., Górski A., Dmoch A. 1999. Birds of the valley of the Lower Narew River. Not. Orn. 40: 23-44.

Kruszyk R., Zbroński R. 2002a. Migration of waders (Charadrii) at the sediment-ponds and floods of coalmines in Jastrzębie Zdrój. Ring 24, 1: 105-119.

Kruszyk R., Zbroński R. 2002b. Waterfowl of the fishponds near Pawłowice Śląskie. Chrońmy Przyr. Ojcz. 58, 6: 32-51.

Kube J. 1988. Zum Limikolendurchzug im Unteren Odertal (1976-1986). Beitr. Vogelkd. 34: 177-193.

Kuźniak S., Lorek G. 1993. Birds of Wonieść Reservoir and surrounding areas (Western Poland). Pr. Zakł. Biol. i Ekol. Ptaków UAM. vol. 2. Poznań. 
Martyka R., Skórka P. 2002. Waterfowl of the sedimentation basins of the Nitrogen Works in Tarnów. Chrońmy Przyr. Ojcz. 58, 5: 23-43.

Meissner W. 2001a. Spring migration of Common Snipe Gallinago gallinago, in the Gulf of Gdansk area (Poland). Census results and notes on the methodology. Alauda 69, 3: 429-434.

Meissner W. 2001b. Strategie wędrówkowe siewkowców (Charadrii) zachodniej Palearktyki. Wiad. Ekol. 47: 119-141.

Meissner W., Sikora A. 1995. Spring and autumn migration of waders Charadrii on the Hel peninsula. Not. Orn. 36: 205-237.

Meissner W., Włodarczak A. 1998. Spring migration of waders Charadrii in the area of the projected „Rzeczne Eaki” reserve at the Bay of Puck. Not. Orn. 39: 219-229.

Mitrus C., Kuczborski R., Słupek J. 1998. Autumn passage of the Common Sandpiper Actitis hypoleucos in the Bug River valley - dynamics and biometry. Not. Orn. 39: 13-25.

Sikora A., Meissner W., Skakuj M. 1994. Rare birds species recorded at the Bay of Gdańsk in 1983-1989. Not. Orn. 35: 207-243.

Słychan M. 1996. Birds of Wroctaw sewage farm. Ptaki Sląska 11: 133-150.

Stajszczyk M. 1994. Birds of the Odra valley between Brzeg and Otawa. Ptaki Śląska 10: 78-89-98.

Staszewski A., Kaliciuk J. 1995. Avifauna of the Zalew Kamieński lagoon and its environs in 1979-1992. Not. Orn. 36: 75-97.

Stawarczyk T., Grabiński W., Karnaś A. 1996. Migration of Charadriiformes at Nyski and Turawski Reservoir in 1976-94. Ptaki Śląska 11: 39-80.

Szyra D. 2004. The birds of nature and landscape complex Wielikat. Przegl. Przyr. 15: 77-104.

Szyra D., Szyra R. 2004. Waterfowl of he fishponds in Ligota in 1995-1999. Ptaki Śląska 15: 49-61.

Tomiałojć L., Stawarczyk T. 2003. Awifauna Polski. Rozmieszczenie, liczebność i zmiany. PTPP "pro Natura", Wrocław.

Wiehle D., Wilk T., Faber M., Betleja J., Malczyk P. 2002. Avifauna of the upper Vistula River walley - part 1. Birds of the Ziemia Oświęcimsko-Zatorska region. Not. Orn. 43: 227-253.

Witkowski J., Orłowska B., Ranoszek E., Stawarczyk T. 1995. The avifauna of the Barycz River valley. Not. Orn. 36: 5-74.

Witkowski J., Ranoszek E. 1998. Migration of waders in the fish-ponds of the Barycz valley. Ptaki Sląska 12: 113-125.

Wójcik C., Rydzkowski P., Ściborski M. 1999. The spring migration of waders (Charadrii) in the lower Vistula valley. Ring 21: 79-90.

Wysocki D. 1996. Waterfowl of the sewage water reservoirs of the Chemical Plant „Police”. Not. Orn. 37: 55-70.

Zieliński M. 1995. Waders ringing of Vistula River mouth in 1987-1994. Not. Orn. 36: 181-190.

Zieliński M., Studziński S. 1996. Avifauna of the marshland of Btota Rakutowskie near Wtoctawek. Not. Orn. 37: 259-300. 